\title{
Manganese Inhibits Viability of Prostate Cancer Cells
}

\author{
BODIL HERNROTH ${ }^{1,2}$, INGVAR HOLM $^{1}$, ANDREAS GONDIKAS ${ }^{3}$ and HELENA TASSIDIS ${ }^{1}$ \\ ${ }^{1}$ Department of Natural Science, Kristianstad University, Kristianstad, Sweden; \\ ${ }^{2}$ The Royal Swedish Academy of Sciences, Fiskebäckskil, Sweden; \\ ${ }^{3}$ Department of Marine Sciences, University of Gothenburg, Göteborg, Sweden
}

\begin{abstract}
Background/Aim: Androgen deprivation therapy is usually in the initial phase a successful treatment for prostate cancer but eventually most patients develop androgen-independent metastatic disease. This study investigated if manganese $(\mathrm{Mn})$ reduces viability of prostate cancer via induction of apoptosis. Materials and Methods: The prostate cancer cell lines PC3, DU145 and LNCaP underwent dose- and time-dependent screening of viability, analyzed by the 3-(4,5-dimethyl-thiazol-2-yl)-2,5-diphenyltetrazolium bromide assay. Flow cytometry was used for the cell-cycle and apoptosis analyses. Intracellular $\mathrm{Mn}$ concentration was measured using inductively coupled plasma-mass spectrometry. Results: At Mn concentrations of 200-1000 $\mu \mathrm{M}$, the effect on viability was most pronounced in PC3 followed by LNCaP cells. These cell lines also showed higher intracellular concentration of $\mathrm{Mn}$ compared to DU145. In all cell lines, Mn increased the proportion of cells arrested in the $G_{0} / G_{1}$ phase and induced apoptosis. Conclusion: To our knowledge, this is the first report demonstrating Mn as a potential agent in prostate cancer therapy.
\end{abstract}

Prostate cancer was the second most common cancer in men worldwide in 2012, with a rate of 94.9 and 85 per 100,000 men (age-standardized) in Western and Northern Europe (1). It can progress from a clinically localized androgen-sensitive primary tumor to androgen-independent metastatic disease. Androgen-sensitive tumors initially respond to hormonal therapy. However, within 1-3 years of treatment, most patients develop castration-resistant tumors due to

This article is freely accessible online.

Correspondence to: Helena Tassidis, Department of Natural Science, Kristianstad University, SE-291 88 Kristianstad, Sweden. Tel: +460722115801, e-mail helena.tassidis@hkr.se

Key Words: Manganese, cell viability, apoptosis, prostate cancer, PC3, DU145, LNCaP. amplification of the androgen receptor or alteration of signal transduction pathways. At this androgen-independent stage, use of chemotherapeutic agents such as the mitotic spindle inhibitor docetaxel have contributed to a significant increase in survival rate (2). Successful chemotherapy of patients with late-stage metastatic prostate cancer is dependent on cells being able to maintain their ability to undergo apoptosis. However, tumor cells inherit the ability to avoid apoptosis, and this is an underlying molecular reason contributing to disease progression and chemotherapy resistance (3). Development of therapies that focus on these mechanisms is thus essential.

Manganese $(\mathrm{Mn})$ is a highly abundant metal in nature, mostly present in inorganic forms. As a trace metal, it plays essential roles for human, animals and plants, and takes part in many metabolic functions, cellular protection, bone and skeleton mineralization processes and reproductive mechanisms (4). However, it is known that humans exposed to high doses of bioavailable Mn, e.g. miners and welders inhaling Mn dust, may suffer neuronal injury, resembling Parkinson's disease $(5,6)$. Studies on PC12 cells derived from the adrenal gland in rats, showed that Mn induces DNA fragmentation, a characteristic marker of apoptosis (7). Deng et al. showed that Mn exposure of cultured astrocytes from rats inhibits cell viability, elevates the level of lactate dehydrogenase (LDH) leakage, and induces $G_{0} / G_{1}$ phase arrest and apoptosis (8). Studies on the arthropod Nephrops norvegicus have demonstrated that an excess of $\mathrm{Mn}$ inhibits proliferation of hematopoietic stem cells and induces apoptosis of these precursor cells (9). The literature is sparse on how overexposure to this trace metal affects human cells but some toxicological studies have been conducted. Pascal and Tessier showed that $\mathrm{Mn}$ is cytotoxic to human lung epithelial cells (10) and Zhao et al. reported that $\mathrm{Mn}$ induced $\mathrm{G}_{0} / \mathrm{G}_{1}$ and $\mathrm{S}$ phase arrest in a human lung adenocarcinoma cell line (11). It has also been shown that $\mathrm{Mn}$ induces apoptosis of HeLa and NIH3T3 cells through the activation of the caspase-12 pathway $(12,13)$ and via caspase- 8 pathway in human lymphoma B-cells (14). 
As reviewed by Desoize (15), metal ions have been used for a considerable time as anticancer agents, e.g. platinum [in the form of cis-diamminedichloridoplatinum(II)] but the results of treatments are not yet satisfactory. To our knowledge, there have been no studies of the effect of Mn on prostate cancer cells. Here, we aimed to take advantage of the acquired knowledge of the ability of Mn to induce apoptosis in order to explore its potential of being used as tumor suppressor. This could open up future development of a more sustainable treatment of prostate cancer. Analyses of cell viability, morphology, cell-cycle progression and apoptosis after Mn exposure were conducted to evaluate dose and time response.

\section{Materials and Methods}

Cell culture and reagents. Three human prostate cell lines (PC3, DU145 and LNCaP obtained from the American Type Culture Collection, Manassas, VA, USA) were used in this study. PC3 cells derived from bone metastasis and DU145 cells derived from brain metastasis were maintained in in Dulbecco's modified Eagle's medium (DMEM; Life Technologies, Grand Island, NY, USA). The cell line LNCaP, derived from metastasis of lymph nodes, were maintained in Roswell Park Memorial Institute 1640 (RPMI 1640; Life Technologies) medium. For maintaining cells, they were cultured in T-75 culturing flasks (Sarstedt, Nümbrecht, Germany) in media supplemented with $10 \%$ fetal calf serum (FCS; Life Technologies) and $1 \%$ penicillinstreptomycin (PenStrep; $100 \mathrm{U} / \mathrm{ml}$; Sigma-Aldrich, St. Louis, MO, USA). The cell cultures were kept in a humidified atmosphere with 5\% $\mathrm{CO}_{2}$ at $37^{\circ} \mathrm{C}$ and media were changed twice a week and cells were passaged once a week before reaching confluence.

For the experiments, cells were washed with $\mathrm{Ca}^{2+}$ and $\mathrm{Mg}^{2+}$ free Dulbecco's phosphate-buffered saline (D-PBS; Life Technologies), trypsinized, counted microscopically in a Bürker chamber and seeded into plates. Appropriate cell density was reached in culturemedia without PenStrep following incubation in a humidified atmosphere of $5 \% \mathrm{CO}_{2}$ at $37^{\circ} \mathrm{C}$ over night to allow them to attach. $\mathrm{MnCl}_{2}$ was dissolved in Hepes buffer $(10 \mathrm{mM}$ Hepes) and $0.14 \mathrm{M} \mathrm{NaCl}$; pH 7.6 (Sigma-Aldrich) before starting exposure to $\mathrm{Mn}$ as described below for the different experiments.

Cell viability assay. Cell viability was assessed using the 3-(4,5dimethylthiasol-2-yl)-2,5 diphenyltetrazolium bromide (MTT) reduction assay (Roche Diagnostics GmbH, Germany, Penzberg, Germany). The MTT assay is based on the reduction of the substrate tetrazolium salt, to the reaction product formazan, by the succinate - tetrazolium reductase system located in the respiratory chain of the mitochondria. Since the reaction is only active in metabolically intact cells, the assay is commonly utilized to estimate cellular viability following exposure to drugs as the number of viable cells is proportional to the production of formazan $(16,17)$. The assay was carried out according to the manufacturer's instruction. Cells seeded into 96-well plates at a cell density of 5,000 cells/well were treated with 0 (control), 1, 10, 50, 200, 500, 1,000, 2,000 or 5,000 $\mu \mathrm{M} \mathrm{Mn}$, and after 24, 48, 72 and $96 \mathrm{~h}, 0.5 \mathrm{mg} / \mathrm{ml}$ MTT was added and the optical density was measured in a microplate reader after solubilization (Victor ${ }^{\mathrm{TM}}$ X4, \# 2030 Multilabel Reader; Perkin Elmer Inc., Akron, OH, USA) at wavelength of $595 \mathrm{~nm}$. Viability was calculated in relation to that of control cells (\%).
Morphological observations. Cells were plated in 24-well plates and after reaching $60 \%$ confluency they were treated with $0,10,50,200$ or $1,000 \mu \mathrm{M} \mathrm{Mn}$ for $24,48,72$ and $96 \mathrm{~h}$. After exposure, the cells were stained with 4',6-diamidino-2-phenylindole (DAPI) (Roche Diagnostics) for $45 \mathrm{~min}$ to $1 \mathrm{~h}$ and the morphology was observed and documented using Zoe ${ }^{\mathrm{TM}}$ Fluorescent Cell Imager (BioRad Laboratories, Inc., Hercules, CA, USA).

Cell cycle analysis. Propidium iodide (PI) was used for analyzing DNA content in order to determine cell-cycle progression. Cells were plated in $6 \mathrm{~cm}$ plates and after reaching $60 \%$ confluency they were treated with $0,50,200$ or $1,000 \mu \mathrm{M}$ Mn for 24 or $48 \mathrm{~h}$. Detached cells were collected with the medium and attached cells were collected by trypsinization, washed with PBS and fixed with $70 \%$ ice-cold ethanol overnight at $4^{\circ} \mathrm{C}$. Cells were again washed with PBS and treated with $50 \mathrm{mg} / \mathrm{ml}$ RNase A (Roche) and 50 $\mathrm{mg} / \mathrm{ml}$ PI (Sigma-Aldrich) for $30 \mathrm{~min}$ in the dark at room temperature. The cells were then subjected to flow cytometry (Novocyte $^{\mathrm{TM}}$; ACEA Bioscience, San Diego, CA, USA) and aspirated at a low flow rate $(14 \mu \mathrm{l} / \mathrm{min})$ to minimize analysis of cell doublets which may interfere the determination of DNA content. Data of 10,000 events were collected for each sample. Data acquisition and cell-cycle distribution (Watson model) were carried out using NovoExpress (Novocyte ${ }^{\mathrm{TM}}$; ACEA). A coefficient of variation of less than $5 \%$ was considered as an acceptable analysis.

Apoptosis analysis. Annexin V Apoptosis Detection Kit Fluorescein Isothiocyanate (FITC) (eBioscience, San Diego, CA, USA) was used to determine phosphatidyl serine externalization and membrane integrity according to manufacture's instructions. Cells were plated and exposed to $\mathrm{Mn}$ as described above before being washed in D-PBS, resuspended in $195 \mu \mathrm{l}$ of $1 \mathrm{x}$ binding buffer and stained with $5 \mu$ l annexin V-FITC. After 10-min incubation at room temperature in the dark, the cells were washed with $1 \mathrm{x}$ binding buffer and resuspended in $190 \mu \mathrm{l} 1 \mathrm{x}$ binding buffer and then $10 \mu \mathrm{l}$ PI was added. The cells were analyzed by flow cytometry (Novocyte $^{\mathrm{TM}}$; ACEA). Data acquisition was carried out using NovoExpress (Novocyte ${ }^{\mathrm{TM}}$; ACEA), FITC-positive cells were designated as early-stage apoptotic cells, PI-positive cells were designated as necrotic cells and PI/FITC-positive cells were designated as late-stage apoptotic cells.

Intracellular manganese. Cells were seeded in $10 \mathrm{~cm}$ plates and after reaching $80 \%$ of confluency were exposed to $\mathrm{Mn}(0,10,50$, 200 and $1000 \mu \mathrm{M})$ for $48 \mathrm{~h}$. Detached and attached cells were harvested and pooled from three culture flasks of each cell line $(n=2)$ and washed by centrifugation three times in PBS. Cell pellets were resuspended in approximately $500 \mu \mathrm{l}$ PBS and digested in $20 \% \mathrm{HNO}_{3}$ at $120^{\circ} \mathrm{C}$ at 1.2 bar for $20 \mathrm{~min}$. Dissolved $\mathrm{Mn}$ was measured with inductively coupled plasma-mass spectrometry (NexION 350D; Perkin Elmer Inc., Shelton, CT, USA). Samples were diluted $1 / 99 \mathrm{v} / \mathrm{v}$ in $1 \%$ nitric acid solution before measurement of $\mathrm{Mn}$ in standard mode using ULTRA Scientific (Kingstown, RI, USA) $1.000 \mathrm{ppm}$ standard diluted in $1 \% \mathrm{HNO}_{3}$ to $0.01,0.1,1$, and $10 \mathrm{ppb}$. No elemental corrections for polyatomic interferences were deemed necessary. Blanks and calibration standards were prepared in solutions containing experimental blanks (cells not exposed to manganese treatment) diluted $1 / 99 v / v$ in $1 \%$ nitric acid solution. 

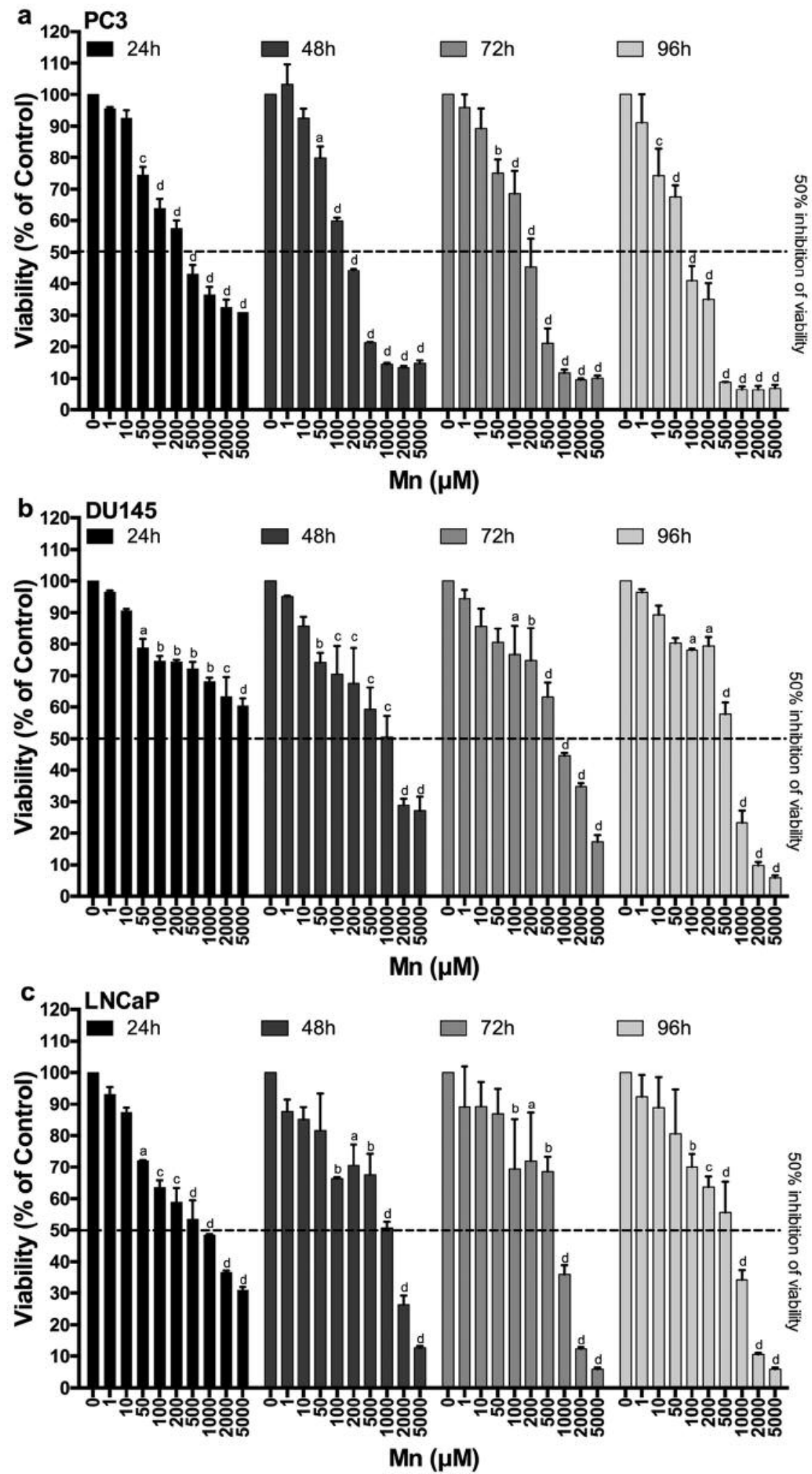

Figure 1. Effect of Mn on cell viability of PC3 cells (a), DU145 (b) and LNCaP (c) prostate cancer cells. Cells were treated with different concentrations of Mn for 24, 48, 72 and $96 \mathrm{~h}$ and the viability was analyzed by dimethyl-thiazol-2-yl)-2,5-diphenyl-tetrazolium bromide. Data are expressed as mean \pm SEM of two independent experiments performed in triplicates. Letters indicate significant difference at: ${ }^{a} p<0.05$, ${ }^{b} p<0.01$, ${ }^{c} p<0.001$ and ${ }^{d} p<0.0001$ relative to the control $(0)$. 


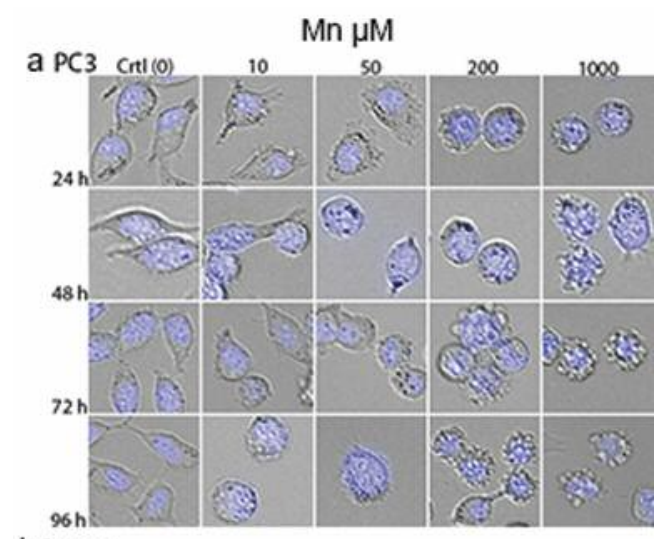

bDU145
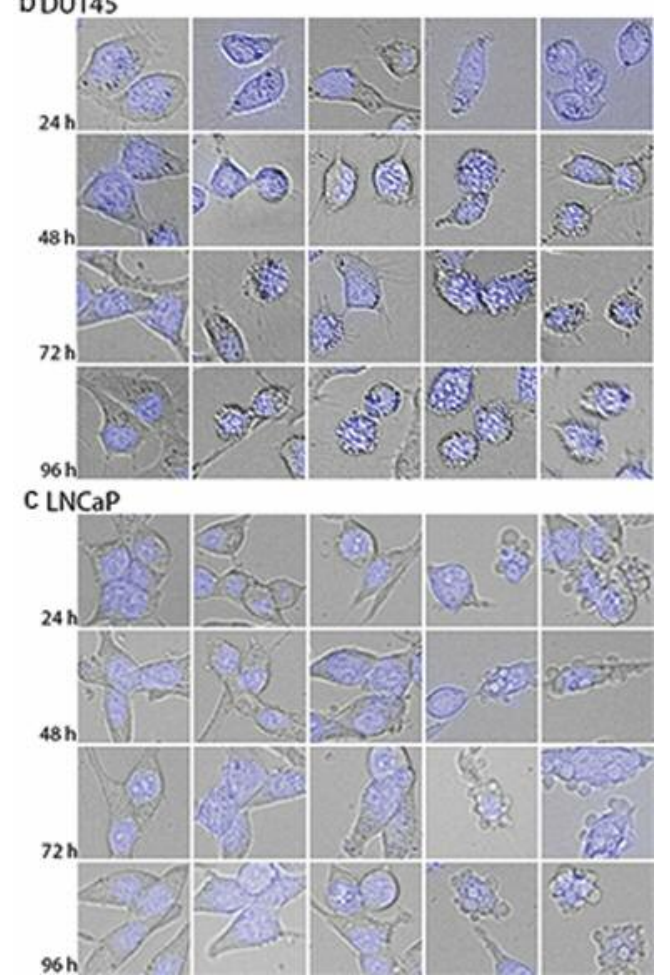

Figure 2. Morphology of PC3 (a), DU145 (b) and LNCaP (c) prostate cancer cells exposed to different concentrations of Mn for 24, 48, 72 and 96 h. Ctrl: Control. Images magnified $\times 20$ with digital zoom.

Statistical data analysis. All data presented are the mean \pm SEM from two independent experiments and for MTT analysis, the two experiments were performed with three replicates. The data were analyzed using two-way analysis of variance (ANOVA; factors: Mn concentration and exposure time) and Tukey test for multiple comparison. Pearson's correlation analysis was used for exploring the potential relationship between cell content of $\mathrm{Mn}$ and cell viability. The statistical analyses were performed using Prism 6 (GraphPad Software, San Diego, CA, USA) and a $p$-value of less than 0.05 was considered to be statistically significant.
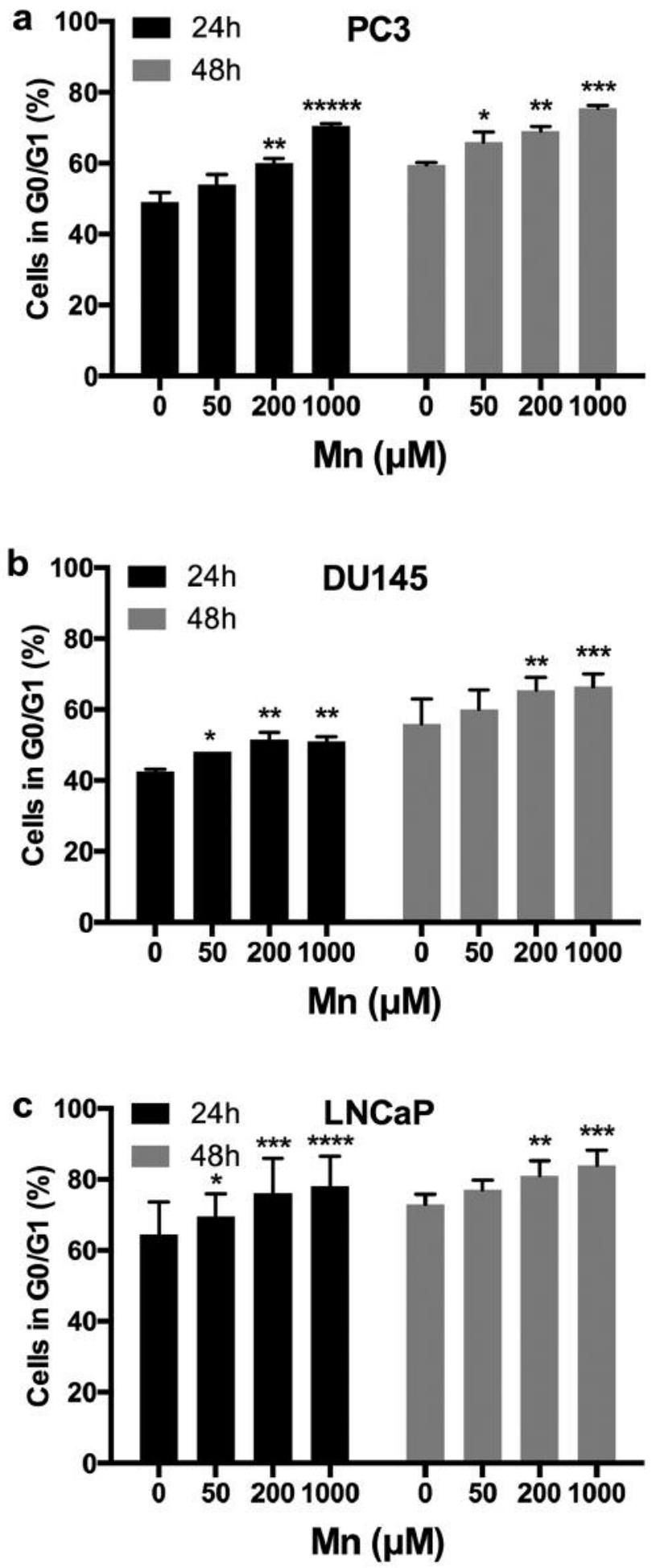

Figure 3. Cell-cycle analysis of cells in $G_{0} / G_{1}$ after Mn treatment in PC3 (a), DU145 (b) and LNCaP (c) presented as a percentage of that of the control cells (not exposed to Mn). Data are expressed as mean $\pm S E M$ of two independent experiments. Statistically significantly different from the control $(0 \mu M \mathrm{Mn})$ at: $* p<0.05,{ }^{*} p<0.01$, $* * * p<0.001$, and $* * * * p<0.0001$. 

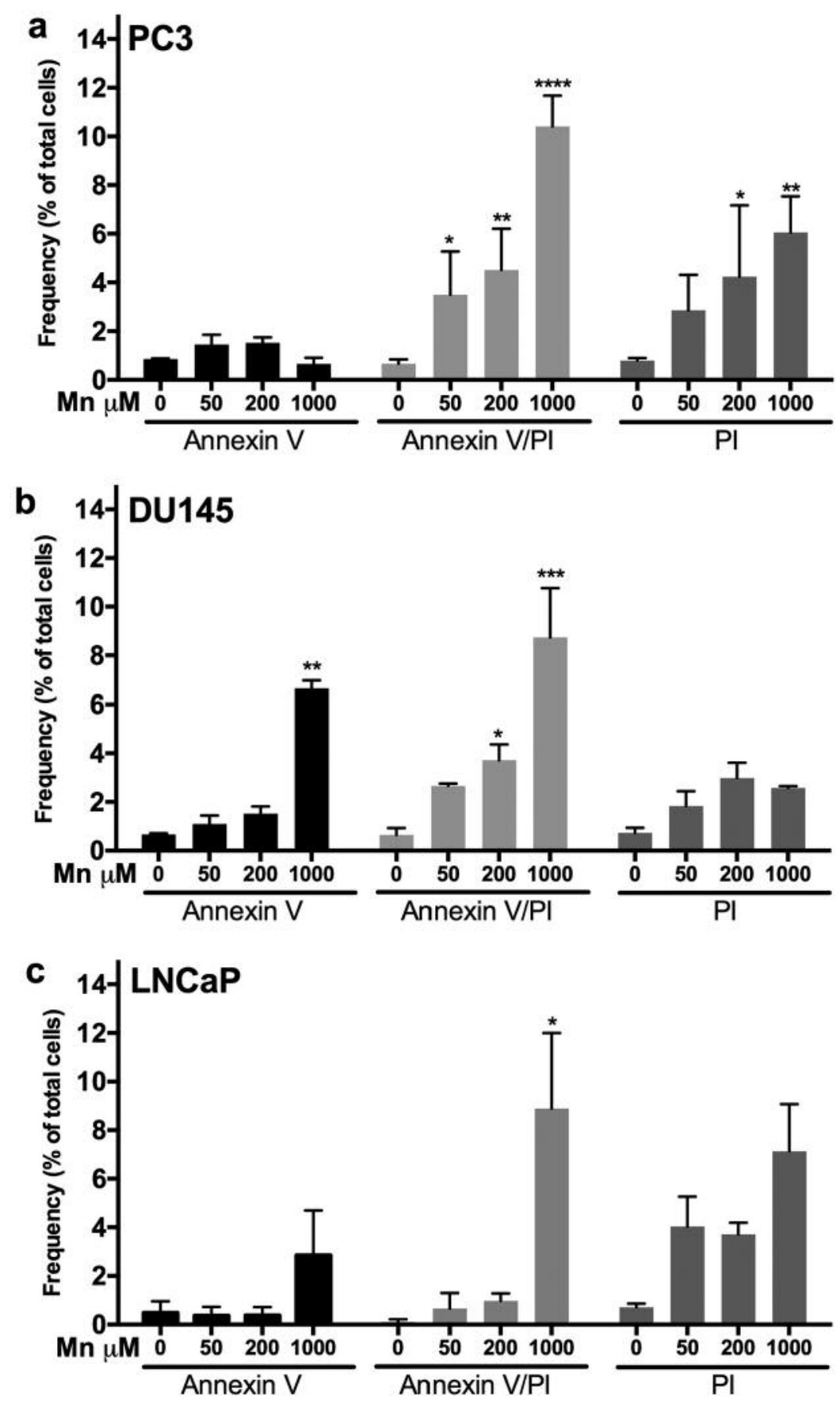

Figure 4. Analysis of apoptosis by flow cytometry after annexinV-fluorescein isothiocyanate (FITC) and propidium iodide (PI) staining. PC3 (a), DU145 (b) and LNCaP (c) cells were treated with different concentrations of Mn for $48 \mathrm{~h}$. Annexin V indicates early apoptosis, AnnexinV/PI indicates late apoptosis and PI indicates necrotic cells. Data are expressed as mean \pm SEM of two independent experiments. Statistically significantly different from the control (0 $\mu \mathrm{M}$ Mn) at: $* p<0.05, * * p<0.01, * * * p<0.001$, and $* * * * p<0.0001$.

\section{Results}

Cell viability. When the prostate cancer cell lines PC3, DU145 and LNCaP were exposed to different concentrations of Mn for different lengths of time, it was shown that $\mathrm{Mn}$ inhibited the viability of all cell lines in a concentrationdependent manner (Figure 1). The viability of PC3 cells was significantly reduced at all time points after exposure 
Table I. Significant differences (p-values) in viability between prostate cancer cell lines.

\begin{tabular}{|c|c|c|c|c|c|c|}
\hline \multirow[b]{2}{*}{ Treatment duration (h) } & \multirow[b]{2}{*}{ Cell line comparison } & \multicolumn{5}{|c|}{ Mn concentration $(\mu \mathrm{M})$} \\
\hline & & 200 & 500 & 1000 & 2000 & 5000 \\
\hline \multirow[t]{3}{*}{24} & PC3 vs. DU145 & $<0.01$ & $<0.0001$ & $<0.0001$ & $<0.0001$ & $<0.0001$ \\
\hline & PC3 vs. LNCaP & $\mathrm{n} . \mathrm{s}$ & $<0.05$ & $<0.01$ & n.s & n.s \\
\hline & DU145 vs. LNCaP & $<0.05$ & $<0.01$ & $<0.01$ & $<0.0001$ & $<0.0001$ \\
\hline \multirow[t]{3}{*}{48} & PC3 vs. DU145 & $<0.01$ & $<0.0001$ & $<0.0001$ & $<0.05$ & n.s \\
\hline & PC3 vs. LNCaP & $<0.0001$ & $<0.0001$ & $<0.0001$ & n.s & n.s \\
\hline & DU145 vs. LNCaP & n.s & $<0.05$ & $\mathrm{n} . \mathrm{s}$ & n.s & $<0.05$ \\
\hline \multirow[t]{3}{*}{72} & PC3 vs. DU145 & $<0.05$ & $<0.001$ & $<0.01$ & $<0.05$ & $\mathrm{n} . \mathrm{s}$ \\
\hline & $\mathrm{PC} 3$ vs. LNCaP & $<0.05$ & $<0.0001$ & $<0.05$ & n.s & n.s \\
\hline & DU145 vs. LNCaP & n.s & $\mathrm{n} . \mathrm{s}$ & n.s & n.s & $\mathrm{n} . \mathrm{s}$ \\
\hline \multirow[t]{3}{*}{96} & PC3 vs. DU145 & $<0.0001$ & $<0.0001$ & ns & n.s & n.s \\
\hline & PC3 vs. LNCaP & $<0.001$ & $<0.0001$ & $<0.01$ & n.s & n.s \\
\hline & DU145 vs. LNCaP & n.s & $\mathrm{n} . \mathrm{s}$ & $\mathrm{n} . \mathrm{s}$ & n.s & $\mathrm{n} . \mathrm{s}$ \\
\hline
\end{tabular}

n.s.: Not significantly different $(p \geq 0.05)$.

to $50 \mu \mathrm{M} \mathrm{Mn}$ and after $96 \mathrm{~h}$ even at $10 \mu \mathrm{M}$ (Figure $1 \mathrm{a}$ ). Neither DU145 cells (Figure 1b) nor LNCaP cells (Figure 1c) showed a significant decrease at $10 \mu \mathrm{M} \mathrm{Mn}$ concentration at any time point. However, after exposure to $100 \mu \mathrm{M}$ Mn, viability of both LNCaP and DU145 cells significantly decreased.

There was no difference at any time point in the viability between the cell lines after exposure to $\mathrm{Mn}$ at concentrations $<200 \mu \mathrm{M}$. With the exception of the highest concentration, the viability of PC3-cells compared to the DU145 cells was significantly lower at 200-5000 $\mathrm{MM}$ after 24,48 and $72 \mathrm{~h}$ (Table I). After $96 \mathrm{~h}$, a significant difference between these cell lines was shown only at 200 and $500 \mu \mathrm{M}$. Moreover, viability of LNCaP cells was lower after $24 \mathrm{~h}$ compared to that of DU145 but at longer exposure times, there was almost no difference. At 200-1000 $\mu \mathrm{M} \mathrm{Mn}$, at all time points PC3 cells generally had lower viability compared to that of LNCaP cells (for details see Table I).

Morphological observations. Microscopic observations of the different cell lines after exposure to different concentrations of Mn for 24-72 h revealed that PC3 cells were most affected. These cells showed morphological features characteristic of apoptosis such as cell shrinkage, cell wall deformation and gradually lower cell density after exposure to $200 \mu \mathrm{M}$ for $24 \mathrm{~h}, 50 \mu \mathrm{M}$ for $48 \mathrm{~h}$ and $72 \mathrm{~h}$, and $10 \mu \mathrm{M}$ for $96 \mathrm{~h}$. Typical apoptotic bodies were seen after 48 $\mathrm{h}$ exposure to $1000 \mu \mathrm{M}$ and to $200 \mu \mathrm{M}$ after 72 and $96 \mathrm{~h}$ (Figure 2a). DU145 cells showed no indication of apoptosis after exposure to the different concentrations of $\mathrm{Mn}$ for $24 \mathrm{~h}$. However after $48 \mathrm{~h}$ exposure to $200 \mu \mathrm{M}$, cell shrinkage and cell wall deformation were apparent (Figure 2b). LNCaP cells showed no indication of apoptosis after exposure to 10 or $50 \mu \mathrm{M} \mathrm{Mn}$ at any time point. However, morphological changes occurred after the cells had been exposed to 200 and $1000 \mu \mathrm{M} \mathrm{Mn}$, with obvious apoptotic cells after $72 \mathrm{~h}$ exposure (Figure 2c).

Cell cycle distribution. The effect of $\mathrm{Mn}$ on cell-cycle progression was analyzed by observing cells in $G_{0} / G_{1}$ phase after exposure to different concentrations of Mn for 48 and 72 h (Figure 3). Compared to the untreated cells, the percentage of cells in $\mathrm{G}_{0} / \mathrm{G}_{1}$ increased after exposure to $200 \mu \mathrm{M} \mathrm{Mn}$ in all cell lines (Figure 3 ).

Apoptosis. Apoptosis was analyzed by staining externalized phosphatidylserine with annexin $\mathrm{V}$ and internalization of PI after exposure to $\mathrm{Mn}$ for $48 \mathrm{~h}$. There were no early apoptotic stages in PC3 and LNCaP cells (Figure 4), however, in DU145 cells, early apoptotic stages were observed after exposure to $1,000 \mu \mathrm{M}$ Mn (Figure 4). In PC3 cells, late apoptotic stages were shown after exposure to all concentrations $(50-1,000 \mu \mathrm{M})$ and in DU145 cells, late stages were recognized at 200 and 1,000 $\mu \mathrm{M} \mathrm{Mn}$. LNCaP cells showed late apoptosis only after exposure to the highest concentration of $\mathrm{Mn}$. There was also an increase in necrosis of PC 3 cells exposed to 200 and 1,000 $\mu \mathrm{M}$ Mn.

Intracellular Mn concentration. Intracellular concentrations of Mn of unexposed cells were similar $(\sim 1.1 \mu \mathrm{M})$ between the different cell lines PC3, DU145 and LNCaP (Figure 5). After $48 \mathrm{~h}$ of exposure to different concentrations of $\mathrm{Mn}$, the two-way ANOVA showed significant difference between the intracellular Mn concentration of the cell lines $(p=0.003)$ but it differed only after exposure to the highest concentration $(1,000 \mu \mathrm{M} \mathrm{Mn})$. At this exposure, the intracellular Mn concentrations of PC3 $(38.2 \pm 14.3 \mu \mathrm{M})$ and $\operatorname{LNCaP}(34.6 \pm 0.7 \mu \mathrm{M})$ cells were 


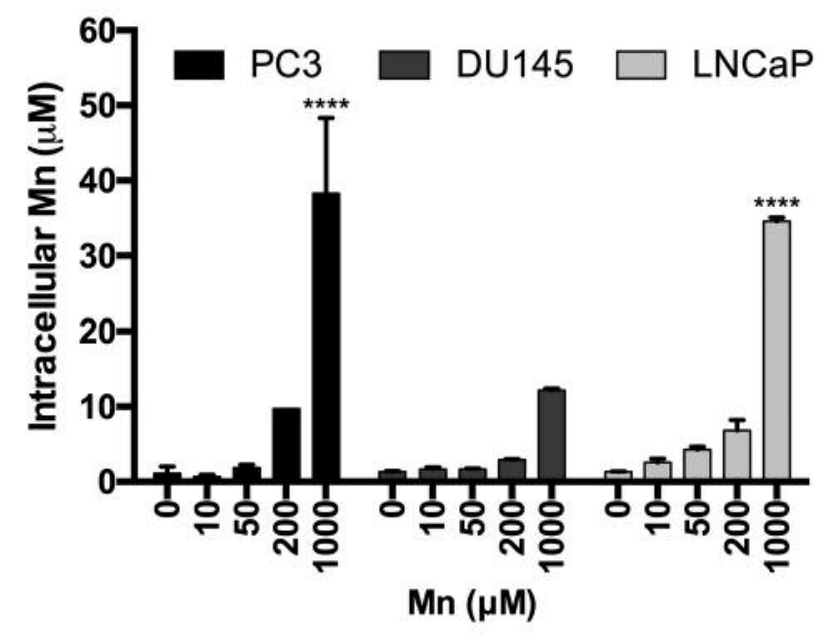

Figure 5. Manganese concentration $(\mu M)$ in PC3, LNCaP and DU145 cells after exposure to different concentration of Mn for $48 \mathrm{~h}$. Significantly different at $* * * * p<0.0001$.

significantly higher compared to those of DU145 cells $(12.2 \pm 0.4 \mu \mathrm{M} ; p<0.001)$. The Mn concentration in DU145 cells did not significantly increase with increasing exposure to $\mathrm{Mn}$. In both PC3 and LNCaP cells, the concentrations of intracellular $\mathrm{Mn}$ gradually increased after exposure to $50 \mu \mathrm{M}$ and were significantly raised at $1,000 \mu \mathrm{M}(p<0.001)$. Pearson correlation analysis showed that there was a significant increase of intracellular $\mathrm{Mn}$ in both the $\mathrm{PC} 3$ and $\mathrm{LNCaP}-$ cells with decreasing cell viability (correlation coefficient: $-0.929, p<0.05$ and $-0.966, p<0.05$, respectively). For DU145 cells, the correlation coefficient was $-0.816, p=0.09$. The relationships between cell viability and intracellular concentrations of $\mathrm{Mn}$ in the different cell lines are illustrated in Figure 6.

\section{Discussion}

In this in vitro study, it was shown that exposure to $\mathrm{Mn}$ of prostate cancer cell lines PC3, DU145 and LNCaP significantly affected the viability of the cells. The measured MTT reductase activity reflected the decrease in number of metabolic active cells, which were affected both by dose and time. After exposure to $\mathrm{Mn}$ within the concentration range of 200-1000 $\mu \mathrm{M}$, the viability also differed between cell lines. PC3 cells were more sensitive compared to $\mathrm{LNCaP}$ and DU145 cells. When comparing the required dose and time needed to reduce the viability by $50 \%$, it was shown that after $24 \mathrm{~h}$, PC3 cells reached this point at a concentration corresponding to $\sim 350 \mu \mathrm{M} \mathrm{Mn}$, while $1,000 \mu \mathrm{M}$ was needed for LNCaP cells. None of the concentrations led to $50 \%$ reduction in viability of DU145 cells after 24 h but after 48 h of exposure to $1,000 \mu \mathrm{M}$ such an affect was achieved. In
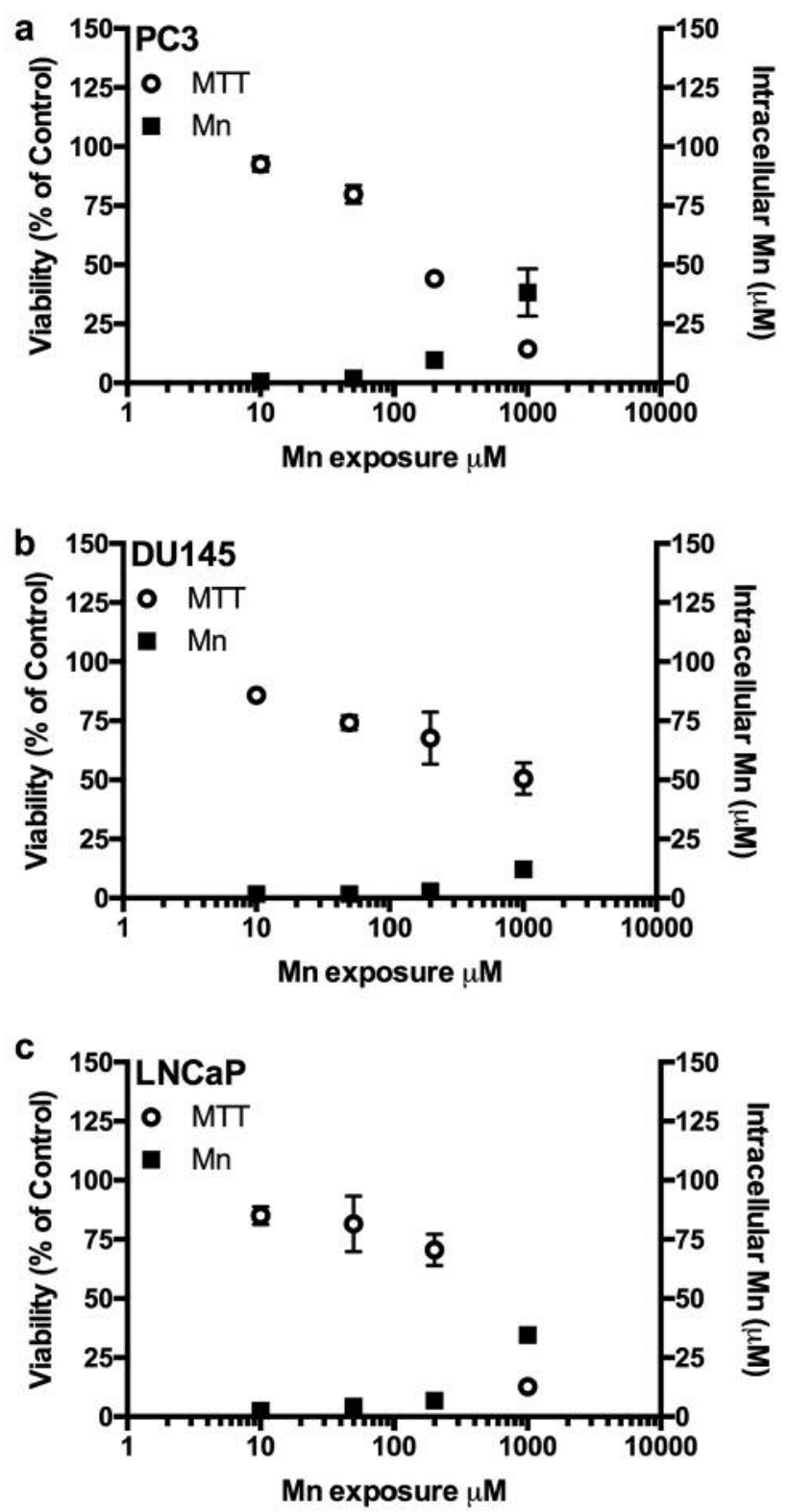

Figure 6. Illustration of the relationship between cell viability (MTT\%) and intracellular concentration of $M n(\mu M)$ after exposing $P C 3(a)$, DU145 (b) and LNCaP (c) cells to different concentrations of Mn for 48 h. $x$-Axis shows the inverse logarithm of Mn concentration.

contrast, at $48 \mathrm{~h}, 50 \%$ reduction was registered for PC3 cells at $\sim 150 \mu \mathrm{M}$. It was demonstrated that after exposure to 2-200 $\mu \mathrm{M}$ of $\mathrm{Mn}$ for $48 \mathrm{~h}$, the viability of lung epithelial cells was significantly reduced (10) and the Mn concentration giving $50 \%$ reduction was comparable to that for the PC3 cells in our study. Similarly, viability of neural stem cells (C17-cells) was significantly reduced after exposure to $50-250 \mu \mathrm{M} \mathrm{Mn}$ for $24 \mathrm{~h}$, reaching $50 \%$ reduction at $\sim 100 \mu \mathrm{M}$ (18). 
Zhao et al. reported that $M n$ induced $\mathrm{G}_{0} / \mathrm{G}_{1}$ and $\mathrm{S}$ phase arrest in a human lung adenocarcinoma cell line (11). Our results also showed that PC3, DU145 and LNCaP cells enter $\mathrm{G}_{0} / \mathrm{G}_{1}$ arrest after $24-\mathrm{h}$ exposure to $200 \mu \mathrm{M} \mathrm{Mn}$. This indicates that the viability of the cells are affected by $\mathrm{Mn}$, but does not verify if this arrest induces cell death. However, it has been reported that $\mathrm{Mn}$ also induces apoptosis of other type of human cells, such as HeLa cells (13) and lymphoma B-cells (14). Most attention regarding Mn toxicity has been directed towards nerve cells, as reviewed by Gerber et al. (19). The upstream molecular mechanisms involved are not yet fully known but the induced toxicity is known to be associated with oxidative stress (20-22). Formation of reactive oxygen species causes DNA damage $(23,24)$, arrests cell proliferation and activates transcription factors triggering apoptosis (25).

Activation of the executioners of apoptosis, the caspases, can be mediated either via the extrinsic pathway through the plasma membrane by the so-called death receptors, or through the intrinsic pathway by mitochondrial proteins $(26$, 27). However, in both HeLa and NIH3T3 cell lines, Mn has been shown to induce apoptosis independently of mitochondria, via a caspase-12 dependent pathway $(12,13)$. The capacity to respond by repairing damaged DNA relies on the level of redox imbalance and is likely to determine whether the cell will undergo apoptosis, necrosis or survive.

It has been reported that neural rat cells exposed to $\mathrm{Mn}$ respond with down-regulation of p53-induced phosphatase 1 (Wipl) which is believed to affect p53 signaling and neuronal apoptosis (28). This indicates that p53 expression may have a protective role against $\mathrm{Mn}$ toxicity. The cell lines used in the present study, PC3, DU145 and LNCaP, have different p53 expression (29). Both LNCaP and DU145 cells have two $17 \mathrm{p}$ alleles and are able to express p53 protein, however, $\mathrm{LNCaP}$ is considered to have wild-type $p 53$, while DU145 expresses a mutated form. PC3 cells only have one $17 \mathrm{p}$ allele (30) and are unable to express p53 (p53-null). This may explain the different success in maintaining viability that was registered after exposure to $200-1,000 \mu \mathrm{M}$ of $\mathrm{Mn}$.

At the higher concentrations, 2000 and 5,000 $\mu \mathrm{M}$, the differences between the cell lines were less pronounced, particularly after the longer exposure times, 72 and $96 \mathrm{~h}$. Then viability was in general below $10 \%$ and there were morphological signs of cell damage due to apoptosis and necrosis, indicating that $\mathrm{Mn}$ at these concentrations was beyond any therapeutic value. Therefore, flow cytometry using annexin $\mathrm{V}$ and PI to discriminate between apoptotic and necrotic cell death was conducted after exposure to $0-1,000 \mu \mathrm{M}$ of $\mathrm{Mn}$ for 48 h. Only PC3 cells showed a significantly increase in PIpositive cells after 200 and $1000 \mu \mathrm{M}$ exposure, which indicates that the cells underwent necrosis. Even at $50 \mu \mathrm{M}$, there was an increased proportion of doubly stained cells, indicating cells at a late stage of apoptosis. Early-stage apoptosis was only found in DU145 cells exposed to $1,000 \mu \mathrm{M}$, while late-stage apoptosis was found at this concentration in both DU145 and LNCaP cells. Thus it was concluded that Mn induced apoptosis of all the cell lines but some of the more sensitive PC3 cells were even forced into necrosis. Seemingly, a concentration below $200 \mu \mathrm{M}$, and a shorter exposure time should be appropriate for inducing apoptosis of PC3 cells while at the same time avoiding necrosis.

\section{Conclusion}

Recent cancer research has recognized apoptosis as being central to the regulation of tumor formation and therapy. Here we can conclude that a cost-effective and easily accessible metal, Mn, has potential as a therapeutic option to inhibit growth of prostate cancer cells. The cytotoxicity of Mn was seemingly reflected by the intracellular amount of the metal. The highest intracellular concentrations of $\mathrm{Mn}$ after $48 \mathrm{~h}$ of exposure to 200-1,000 $\mu \mathrm{M}$ were found in PC3 and LNCaP cells and it was also these cell lines which were most affected in viability and morphology. On the other hand, the flow cytometric analyses revealed that $\mathrm{Mn}$ increased cell-cycle arrest and apoptosis in all three cell lines, of which PC3 cells were the most sensitive and even reached a degree of necrosis. These findings will enable further studies of relevant doses of $\mathrm{Mn}$ in the exploration of apoptotic pathways and the possibility to combine Mn treatment with other chemotherapeutic agents.

\section{Conflicts of Interest}

The Authors declare no conflict of interest in regard to this study.

\section{Acknowledgements}

This study was funded by the research board of Kristianstad University. The Authors thank Alice Nilsson for excellent experimental and laboratory assistance.

\section{References}

1 Ferlay J, Soerjomataram I, Dikshit R, Eser S, Mathers C, Rebelo M, Parkin DM, Forman D and Bray F: Cancer incidence and mortality worldwide: sources, methods and major patterns in GLOBOCAN 2012. Int J Cancer 136: E359-386, 2015.

2 Fujimoto N: Role of the androgen-androgen receptor axis in the treatment resistance of advanced prostate cancer: from androgendependent to castration resistant and further. J UOEH 38: 129138, 2016.

3 Gleave M, Miyake $\mathrm{H}$ and Chi K: Beyond simple castration: targeting the molecular basis of treatment resistance in advanced prostate cancer. Cancer Chemother Pharmacol 56(Suppl 1): 47$57,2005$.

4 Santamaria AB: Manganese exposure, essentiality and toxicity. Indian J Med Res 128: 484-500, 2008.

5 Iregren A: Psychological test performance in foundry workers exposed to low levels of manganese. Neurotoxicol Teratol 12: 673-675, 1990. 
6 Mena I, Marin O, Fuenzalida S and Cotzias GC: Chronic manganese poisoning. Clinical picture and manganese turnover. Neurology 17: 128-136, 1967.

7 Hirata Y: Manganese-induced apoptosis in PC12 cells. Neurotoxicol Teratol 24: 639-653, 2002.

8 Deng Y, Xu D, Xu B, Xu Z, Tian Y, Feng W, Liu W and Yang $\mathrm{H}$ : $\mathrm{G}_{0} / \mathrm{G}_{1}$ phase arrest and apoptosis induced by manganese chloride on cultured rat astrocytes and protective effects of riluzole. Biol Trace Elem Res 144: 832-842, 2011.

9 Oweson CA, Baden SP and Hernroth BE: Manganese induced apoptosis in haematopoietic cells of Nephrops norvegicus (L.). Aquat Toxicol 77: 322-328, 2006.

10 Pascal LE and Tessier DM: Cytotoxicity of chromium and manganese to lung epithelial cells in vitro. Toxicol Lett 147: 143-151, 2004.

11 Zhao P, Zhong W, Ying X, Yuan Z, Fu J and Zhou Z: Manganese chloride-induced $G_{0} / G_{1}$ and $S$ phase arrest in A549 cells. Toxicology 250: 39-46, 2008.

12 Oubrahim H, Chock PB and Stadtman ER: Manganese(II) induces apoptotic cell death in NIH3T3 cells via a caspase-12dependent pathway. J Biol Chem 277: 20135-20138, 2002.

13 Oubrahim H, Stadtman ER and Chock PB: Mitochondria play no roles in $\mathrm{Mn}$ (II)-induced apoptosis in HeLa cells. Proc Natl Acad Sci USA 98: 9505-9510, 2001.

14 El Mchichi B, Hadji A, Vazquez A and Leca G: p38 MAPK and MSK1 mediate caspase- 8 activation in manganese-induced mitochondria-dependent cell death. Cell Death Differ 14: 18261836, 2007.

15 Desoize B: Metals and metal compounds in cancer treatment. Anticancer Res 24: 1529-1544, 2004.

16 Alley MC, Scudiero DA, Monks A, Hursey ML, Czerwinski MJ, Fine DL, Abbott BJ, Mayo JG, Shoemaker RH and Boyd MR: Feasibility of drug screening with panels of human tumor cell lines using a microculture tetrazolium assay. Cancer Res 48 : 589-601, 1988.

17 Mosmann T: Rapid colorimetric assay for cellular growth and survival: application to proliferation and cytotoxicity assays. J Immunol Methods 65: 55-63, 1983.

18 Tamm C, Sabri F and Ceccatelli S: Mitochondrial-mediated apoptosis in neural stem cells exposed to manganese. Toxicol Sci 101: 310-320, 2008.

19 Gerber GB, Leonard A and Hantson P: Carcinogenicity, mutagenicity and teratogenicity of manganese compounds. Crit Rev Oncol Hematol 42: 25-34, 2002.
20 Erikson KM, Dobson AW, Dorman DC and Aschner M: Manganese exposure and induced oxidative stress in the rat brain. Sci Total Environ 334-335: 409-416, 2004.

21 Martinez-Finley EJ, Gavin CE, Aschner M and Gunter TE: Manganese neurotoxicity and the role of reactive oxygen species. Free Radic Biol Med 62: 65-75, 2013.

22 Milatovic D, Yin Z, Gupta RC, Sidoryk M, Albrecht J, Aschner $\mathrm{JL}$ and Aschner M: Manganese induces oxidative impairment in cultured rat astrocytes. Toxicol Sci 98: 198-205, 2007.

23 Franco R, Schoneveld O, Georgakilas AG and Panayiotidis MI: Oxidative stress, DNA methylation and carcinogenesis. Cancer Lett 266: 6-11, 2008.

24 Wiseman $\mathrm{H}$ and Halliwell B: Damage to DNA by reactive oxygen and nitrogen species: role in inflammatory disease and progression to cancer. Biochem J 313(Pt 1): 17-29, 1996.

25 Zhang R, Humphreys I, Sahu RP, Shi Y and Srivastava SK: In vitro and in vivo induction of apoptosis by capsaicin in pancreatic cancer cells is mediated through ROS generation and mitochondrial death pathway. Apoptosis 13: 1465-1478, 2008.

26 Hengartner MO: The biochemistry of apoptosis. Nature 407: 770-776, 2000

27 Zimmermann $\mathrm{KC}$ and Green DR: How cells die: apoptosis pathways. J Allergy Clin Immunol 108: S99-103, 2001.

28 Ma X, Han J, Wu Q, Liu H, Shi S, Wang C, Wang Y, Xiao J, Zhao J, Jiang $\mathrm{J}$ and Wan C: Involvement of dysregulated Wip I in manganese-induced p53 signaling and neuronal apoptosis. Toxicol Lett 235: 17-27, 2015.

29 Carroll AG, Voeller HJ, Sugars L and Gelmann EP: p53 oncogene mutations in three human prostate cancer cell lines. Prostate 23: 123-134, 1993.

30 Isaacs WB, Carter BS and Ewing CM: Wild-type $p 53$ suppresses growth of human prostate cancer cells containing mutant $p 53$ alleles. Cancer Res 51: 4716-4720, 1991.
Received October 13, 2017

Revised November 6, 2017

Accepted November 8, 2017 